\title{
Saudi Parents' Perceptions of the Kind of Help they Offer to their Primary School Kids
}

\author{
Salameh S. Mahmoud ${ }^{1}$ \\ ${ }^{1}$ The Faculty of Engineering, King Abdulaziz University, Jeddah, KSA \\ Correspondence: Salameh S. Mahmoud, the Faculty of Engineering, King Abdulaziz University, Jeddah, KSA. \\ Tel: 054-578-2715. E-mail: ashareen18@gmail.com
}

Received: October 19, 2017 Accepted: February 17, 2018 Online Published: February 19, 2018

doi: 10.5539/elt.v11n3p102 URL: http://doi.org/10.5539/elt.v11n3p102

\begin{abstract}
Parents in the Kingdom of Saudi Arabia usually help their kids in early school years especially in English language. This help varies according to the parents' level of education, the degree of difficulty of the curriculum and the type of school their kids join. Sometimes they give the right kind of help that matches the teachers' strategies and objectives and most of the time their help is in the wrong direction. This study aims at investigating the Saudi parents' perceptions of the kind of help they offer to their primary school kids in order to decide which help is constructive and which is misleading. To this end, the researcher designed a 29-item questionnaire divided into three categories under three subtitles and distributed it to one hundred parents. The results of the study showed that the majority of parents agreed that a healthy constructive parents-teachers relationship is very important for a successful kid at school. It also showed that the parents' help whether direct through helping the kid in homework, assignments or projects or indirect through saving a motivating environment or involving him in cocurricular activities is vital for a fruitful academic life for kids. The study recommended that certain kinds of help such as direct translation to L1or the exaggerated help that sometimes reaches to doing assignments on behalf of kids should be avoinded.
\end{abstract}

Keywords: logistic help, L1, minorities, primary schools, PTA, SNS

\section{Introduction}

Teaching children and educating them is not only the schools' responsibility; parents have a very important role to play in improving students' academic performance (Al- Sumaiti, 2012). Al-Mahrooqi, Denman \& Maamari, (2016) pointed out that parental involvement is of great importance in kids' educational, social, and psychological progress. This progress includes higher rates of attendance, more communication with the school and teachers, and higher levels of academic achievement. Establishing connections between home and school, parents and teachers talking and listening to each other whether face to face or through the telephone or SNS means all have the biggest effect on a child's school success (Academic Development Institute, 1984; Emerson, Fear, Fox, \& Sanders, 2012; Linse, Vlack, \& Bladas, 2014; Green et al., 2007) cited in Linse et al., (2014). Henderson and Berla (1994) cited in Center for Child Well-being (2012) highlighted the importance of the parents' role in creating a home environment that encourages learning, expressing high expectations for children's achievement and future careers and being involved in their children's education. Unfortunately, parents' involvement sometimes face barriers such as negative attitudes of school staff toward them, lack of teacher' preparation and occupational demands that limit parents' involvement (Moosa, Karabenick \& Adams, 2001). There are other barriers facing parents' involvement in poor areas like lack of awareness, literacy, planning and coordination; in addition to the shortage of parent involvement programs and poverty (Lebona, 2010). This research intends to shed more light on the way parents help their kids in KSA in terms of approved and mistaken practices. The researcher also hopes to find out the best practices in this contexts from the related literature and the experts in the field.

\subsection{Questions of the Study}

1) How can parents develop a positive relation with the teaching staff?

2) What kind of help do parents give to their primary school kids with regard to teaching and learning? 
3) What kind of help do parents give to their primary school kids with regard to home environment, relaxing atmosphere, logistic support...etc.?

\section{Review of Literature}

\subsection{The Importance of Involving Parents}

Early childhood educators and specialists, all over the world, recognize the importance of creating positive connections between homes and schools. They think that such connections can hopefully contribute to solving kids' problems that demand special treatment. Below is a literature survey about the relation between home and school that attempts to decide on the types of healthy relations to recommend. On the other hand, the unhealthy relations will be explained and warned of so that parents know that they are unintentionally harming their kids.

Al-Mahrooqi et al. (2016) conducted a study to examine the benefits, challenges and practices of Omani parents in relation to their children's English language studies. The results of the study showed that Omani parents know well that their involvement is important as it will be beneficial to their kids; nevertheless, their involvement is very limited. Linse et al. (2014) aimed at defining the positive home-school communication through surveying authentic contacts between English language teachers and parents of young learners. To do this he analyses different kinds of contacts including face-to-face contacts, telephone calls, written materials that schools send home. Mafa and Makuba (2013) explored the schools involvement of parents in their children's education. Awareness of the importance of involving parents was clear in the results despite the barriers that limited this involvement. In a telephone survey of 5,032 parents and care-takers of children aged 5-16 (Peter's et al., 2008) found out that nearly half of parents felt very involved in their children's school life and women tend to feel more involved than men. More than $70 \%$ think that they should be more involved. $44 \%$ of the sample said that work commitments were the main barrier to greater involvement. Graham-Clay (2005) mentioned some challenges against parent teacher communication. Cultural differences are among these barriers when both can't have the same terms and the result will be confusion and misunderstanding. Another challenge is the short time dedicated for the parent-teacher function which is not enough to talk about the student in terms of behavior, problems in understanding and achievement. Moosa et al. (2001) examined five areas of Arab parent involvement in elementary schools in an urban Midwestern district. Results suggest the following teacher perceptions of Arab parents and their families: a) most view the school as the authority; b) most believe that education is important; c) parents can assist their children with school if given guidance; d) English language skills are important; and e) school-parent communication is tradition bound, with parents reluctant to ask questions. Bempechat (1992) examines parents' involvement in their children's education by exploring socialization patterns that encourage high achievement and describing the nature of parent involvement programs. Involving parents is recognized by all the people involved in the teaching learning process. Parents' attitudes directly affect their kids potential and expectations. There is a shift in parents' responsibility toward child education especially among non-white parents who consider themselves more responsible than schools. $96 \%$ agreed that it is important to make kids attend school regularly (Peters, Seeds, Goldstein, \& Coleman, 2008).

\subsection{How to Involve Parents}

Principals and teachers may think of strategies and ideas to involve parents in the teaching learning process. "Parent Teacher Association (PTA)" is one of the old new ideas that brings parents to school to discuss ideas related to education and to improve the school environment. Other ideas can come from the creativity of the teachers like giving students projects or assignments where kids can ask their parents for help. Paulu (1998) pointed out that homework can bring together children, parents, and teachers in a common effort to enhance students' learning. Teachers act as coordinators in this context. The benefits of homework begin in school and students who complete their homework successfully improve their chances for academic success. Furthermore, homework develops habits and attitudes that work to a student's advantage far beyond the classroom. Qualities like self-discipline, responsibility and love of learning benefit students throughout their lives. Graham-Clay (2005) emphasized the importance of training for teachers on how to effectively communicate with parents as this communication is essential to building a sense of community between home and school.

\section{Method}

\subsection{The Population and Sample of the Study}

The population of the study is all parents who have kids in the primary -stage schools in Jeddah. These schools include British grammar schools and special schools for minorities like Indian, Pakistani, Bangladeshi and Italian schools; in addition to a mixture of schools that follow the government system. Some of these are to some extent lenient like all public schools; others are a little more challenging like private schools. The third type is 
international schools which are the most challenging in terms of syllabus, teaching and testing. The sample of the study is one hundred parents chosen randomly from the population. These are mainly mothers because in the Saudi society women usually stay at home and men go to work. In addition, women tend to be more patient than men with regard to helping kids.

\subsection{Research Design}

This is a survey study that depends on a questionnaire as a data collection tool. The questionnaire consists of three categories. The first category contains nine items related to the relation between parents and teachers. The second category is about the nature of help parents give to their kids and comprises eight items. The indirect help parents can give to their kids in terms of saving a healthy atmosphere, being a good model to them, helping in time management and doing the necessary follow up is represented in the third category which contains twelve items. The questionnaire is validated by a group of experts and piloted on five relative parents outside the sample. The questionnaire was sent to respondents through google as it is an easy way to reach many parents and get the results in pie charts for later analysis.

\section{Results}

The results of the questionnaire comprise three categories. The first nine items are about the relation between parents and teachers. The second eight items are about the nature of help parents give to their primary school kids and finally the third and last group of twelve items is about the logistic indirect help parents give to their kids. The results are first tabulated then represented in bar charts to make them clear and easy to compare.

\subsection{Results of the Questionnaire}

Table 1. The percentages of the respondents' answers to the first nine items of the questionnaire

\begin{tabular}{|c|c|c|c|c|c|}
\hline No. & The Relation with Teachers & Always & Sometimes & Rarely & Never \\
\hline 1 & I keep in touch with teachers. & $44 \%$ & $47 \%$ & $7 \%$ & $2 \%$ \\
\hline 2 & $\begin{array}{l}\text { Teachers phone me when my child misses } \\
\text { an assignment or does poorly in exams. }\end{array}$ & $27 \%$ & $35 \%$ & $25 \%$ & $13 \%$ \\
\hline 3 & $\begin{array}{l}\text { I let the teacher know I am watching my } \\
\text { child's study habits and attitude. }\end{array}$ & $44 \%$ & $41 \%$ & $13 \%$ & $2 \%$ \\
\hline 4 & $\begin{array}{l}\text { I ask the teacher how I can support my } \\
\text { child in areas he/she may need to improve. }\end{array}$ & $41 \%$ & $35 \%$ & $16 \%$ & $8 \%$ \\
\hline 5 & $\begin{array}{l}\text { I share any information that might help the } \\
\text { teacher understand my child. }\end{array}$ & $42 \%$ & $38 \%$ & $12 \%$ & $8 \%$ \\
\hline 6 & $\begin{array}{l}\text { I get a teacher tutor my kid if he has gaps } \\
\text { in certain areas. }\end{array}$ & $21 \%$ & $37 \%$ & $17 \%$ & $25 \%$ \\
\hline 7 & $\begin{array}{l}\text { I thank the teacher when I appreciate } \\
\text { something he has done for my child. }\end{array}$ & $77 \%$ & $18 \%$ & $3 \%$ & $2 \%$ \\
\hline 8 & $\begin{array}{l}\text { The first one to consult is the teacher if } \\
\text { my child is struggling with homework. }\end{array}$ & $23 \%$ & $42 \%$ & $9 \%$ & $26 \%$ \\
\hline 9 & $\begin{array}{l}\text { I make sure that my teaching strategies go } \\
\text { with the teachers' strategies. }\end{array}$ & $43 \%$ & $31 \%$ & $15 \%$ & $11 \%$ \\
\hline
\end{tabular}

Table 1 above shows the percentages of the respondents' answers on the first category of the questionnaire. The four-Likert scale- always, sometimes, rarely, never- was used to reflect the percentages. 


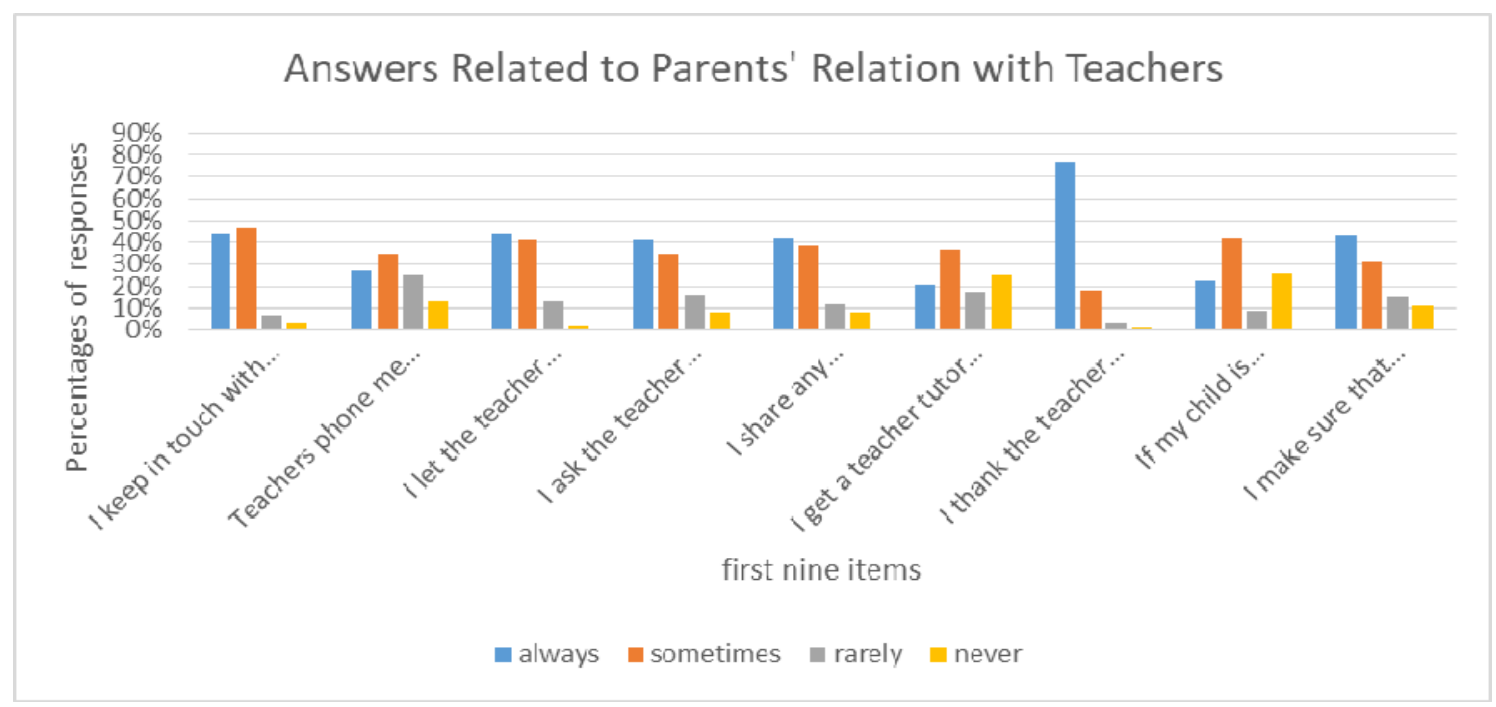

Chart 1 . The students' responses to the first nine items of the questionnaire

Chart 1 above shows the respondents' answers with regard to the first nine items of the questionnaire. These items are related to the parents' relation with teachers. It is clear from the chart that most of the items happen more than often except for items six and eight which are about tutoring and approaching the school teacher in case of difficulty. Thanking the teacher and appreciating him/her got the highest percentage.

Table 2. The percentages of the respondents' answers to the second group of eight items in the questionnaire

\begin{tabular}{|c|c|c|c|c|c|}
\hline No. & $\begin{array}{l}\text { The nature of the help parents give to their } \\
\text { kids }\end{array}$ & Always & Sometimes & Rarely & Never \\
\hline 1 & $\begin{array}{l}\text { Whenever he/she has a difficult word in } \\
\text { English, I give him the Arabic meaning. }\end{array}$ & $60 \%$ & $30 \%$ & $7 \%$ & $3 \%$ \\
\hline 2 & $\begin{array}{l}\text { I make him read texts and give him the } \\
\text { Arabic translation. }\end{array}$ & $40 \%$ & $35 \%$ & $8 \%$ & $7 \%$ \\
\hline 3 & $\begin{array}{l}\text { When he can't answer comprehension } \\
\text { questions, I answer for him. }\end{array}$ & $42 \%$ & $47 \%$ & $10 \%$ & $1 \%$ \\
\hline 4 & I give him the instructions in Arabic. & $39 \%$ & $45 \%$ & $7 \%$ & $9 \%$ \\
\hline 5 & $\begin{array}{l}\text { I encourage my child to work } \\
\text { independently. }\end{array}$ & $51 \%$ & $36 \%$ & $10 \%$ & $3 \%$ \\
\hline 6 & $\begin{array}{l}\text { I watch my children for signs of } \\
\text { frustration or failure. }\end{array}$ & $52 \%$ & $46 \%$ & $2 \%$ & $0 \%$ \\
\hline 7 & $\begin{array}{l}\text { I have my children do harder work first, } \\
\text { when they are most alert. }\end{array}$ & $64 \%$ & $28 \%$ & $7 \%$ & $1 \%$ \\
\hline 8 & $\begin{array}{l}\text { I check my child's diary to know his } \\
\text { assignments every day. }\end{array}$ & $55 \%$ & $39 \%$ & $6 \%$ & $0 \%$ \\
\hline
\end{tabular}

Table 2 above shows the percentages of the respondents' answers on the second category of the questionnaire. The four-Likert scale- always, sometimes, rarely, never- was used to reflect the percentages. 


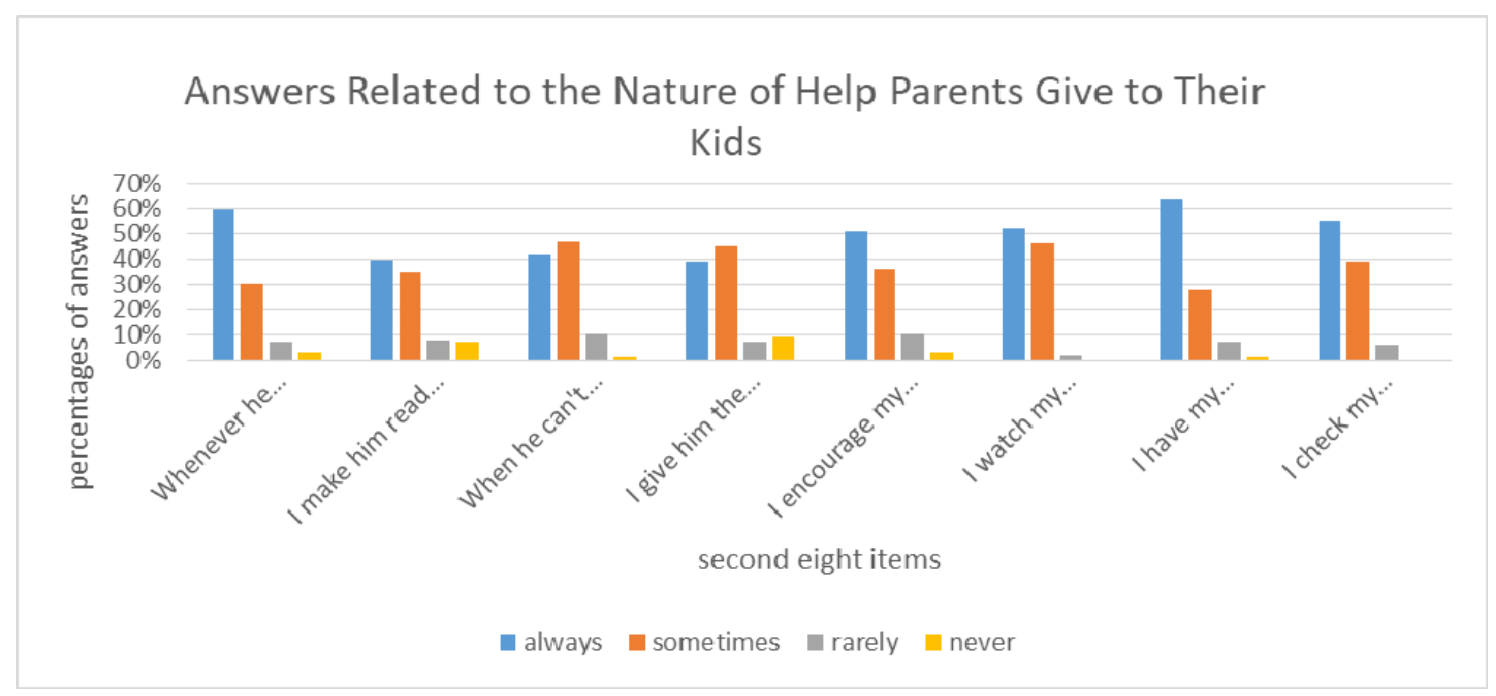

Chart 2. The respondents' answers to the second category of the questionnaire

Chart 2 above shows the respondents' answers with regard to the nature of help parents provide to their primary school kids in international schools. It is apparent that "sometimes" and "always" dominate all the answers to the eight items. "Rarely" is very low and "never" is almost absent in all the responses except for items two and four.

Table 3. The percentages of the respondents' answers to the last twelve items in the third category of the questionnaire

\begin{tabular}{|c|c|c|c|c|c|}
\hline No. & $\begin{array}{l}\text { Logistic and indirect help parents give to } \\
\text { their kids }\end{array}$ & Always & Sometimes & Rarely & Never \\
\hline 1 & $\begin{array}{l}\text { I join SNS groups with parents to follow } \\
\text { up with assignments and exams. }\end{array}$ & $79 \%$ & $19 \%$ & $2 \%$ & $0 \%$ \\
\hline 2 & $\begin{array}{l}\text { I attend PTA meetings to give suggestions } \\
\text { and discuss ideas. }\end{array}$ & $69 \%$ & $21 \%$ & $6 \%$ & $4 \%$ \\
\hline 3 & $\begin{array}{l}\text { I take time to understand my children's } \\
\text { world - their friends, activities, etc. }\end{array}$ & $57 \%$ & $29 \%$ & $10 \%$ & $4 \%$ \\
\hline 4 & $\begin{array}{l}\text { I go with my children to places where } \\
\text { learning is a family activity. }\end{array}$ & $40 \%$ & $35 \%$ & $18 \%$ & $7 \%$ \\
\hline 5 & I make daily study time a family value & $42 \%$ & $47 \%$ & $10 \%$ & $1 \%$ \\
\hline 6 & $\begin{array}{l}\text { I make sure the home environment is } \\
\text { welcoming and motivating to study. }\end{array}$ & $39 \%$ & $45 \%$ & $7 \%$ & $9 \%$ \\
\hline 7 & $\begin{array}{l}\text { I establish a family routine with regular } \\
\text { mealtimes, bedtimes. }\end{array}$ & $51 \%$ & $36 \%$ & $10 \%$ & $3 \%$ \\
\hline 8 & $\begin{array}{l}\text { I show and model courtesy when talking } \\
\text { with my children by using "please", } \\
\text { "thanks" etc. }\end{array}$ & $52 \%$ & $46 \%$ & $2 \%$ & $0 \%$ \\
\hline 9 & $\begin{array}{l}\text { I spend a few minutes daily with each } \\
\text { child, talking and listening with patience } \\
\text { and love. }\end{array}$ & $64 \%$ & $28 \%$ & $7 \%$ & $1 \%$ \\
\hline 10 & $\begin{array}{l}\text { I praise my child for real effort and good } \\
\text { attitudes about school work. }\end{array}$ & $55 \%$ & $39 \%$ & $6 \%$ & $0 \%$ \\
\hline 11 & $\begin{array}{l}\text { I pick a time when my children study each } \\
\text { evening. }\end{array}$ & $79 \%$ & $19 \%$ & $2 \%$ & $0 \%$ \\
\hline 12 & $\begin{array}{l}\text { I try to do some of my own "homework" } \\
\text { while my child studies. }\end{array}$ & $69 \%$ & $21 \%$ & $6 \%$ & $4 \%$ \\
\hline
\end{tabular}


Table 3 above shows the percentages of the respondents' answers on the third category of the questionnaire. The four-Likert scale- always, sometimes, rarely, never- was used to reflect the percentages.

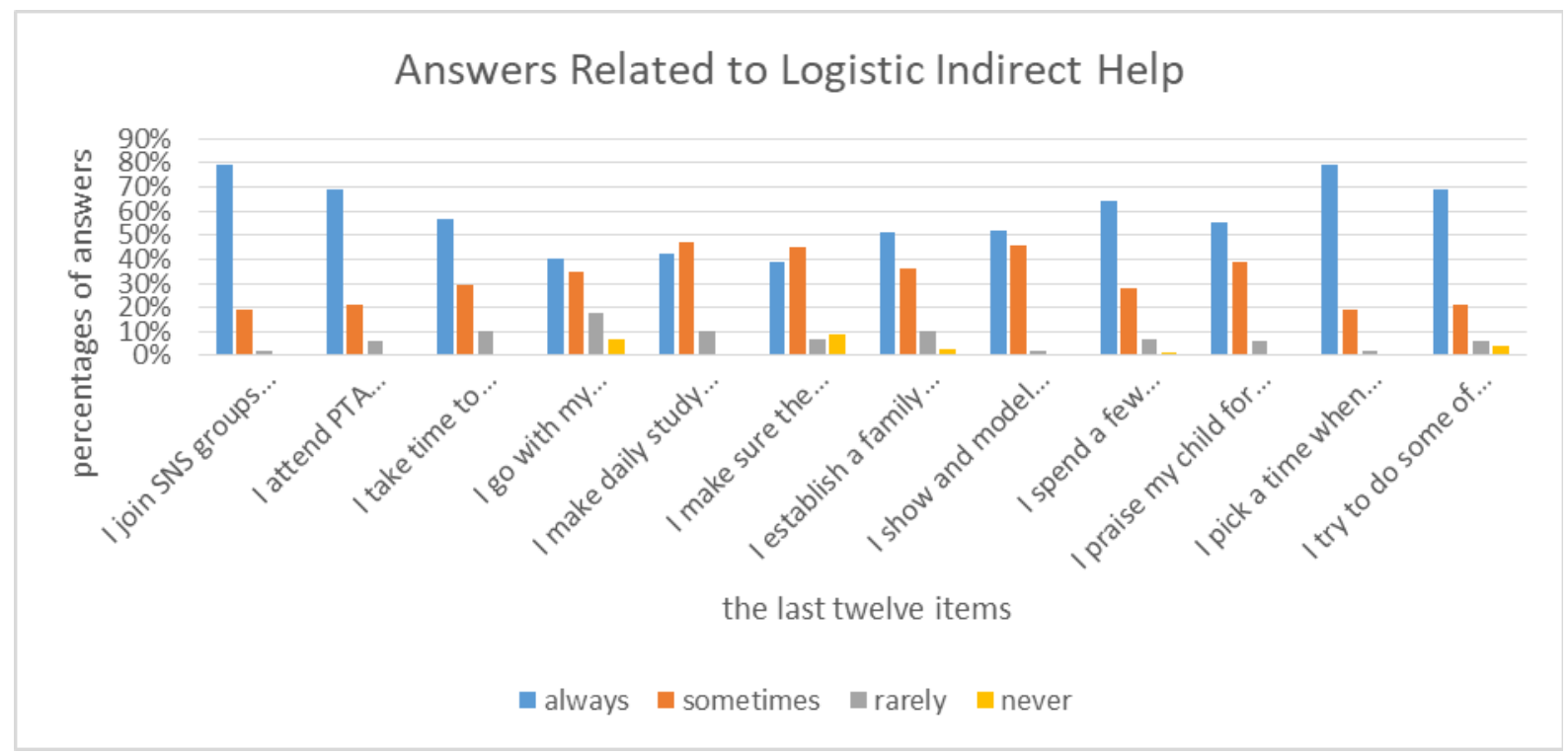

Chart 3. The respondents' answers to the third category of the questionnaire

Chart 3 above shows the respondents' answers to the last twelve items with regard to the logistic indirect help parents provide to their primary school kids in international schools. The four bars reflect the frequency of respondents' answers as explained in chart 1. It is apparent that "always" and "sometimes" exchange the dominance in all the items. Items 1, 2, 3, 11 and 12 got the highest frequency and in all the items "rarely" and "never" are almost absent.

\section{Discussion}

Parent -teacher relation is very important for a successful child. It can keep both of them aware of what is going on inside and outside schools. The results of the questionnaire with regard to parents' relation with teachers support the above assumption. Nearly all responses to the first group of items in the questionnaire were in favor of "always" and "sometimes" with a percentage far higher than 50\%. "I thank the teacher when I appreciate something he has done for my child" had the highest percentage (95\%). This unanimous agreement goes with (Al Sumaiti, 2012; Al-Mahrooqi et al., 2016; and Linse et al., 2014) who highlighted the role of parents in the teaching/learning process. Teachers can't cope with the individual differences among students especially those coming from different backgrounds and different nationalities like the situation in Jeddah, KSA. Parents especially mothers have more time and tend to be more patient with kids and give more examples on condition that they provide the right kind of help and continue what the teacher have already started.

With regard to the question about the nature of help parents give to their kids in terms of teaching and learning, the responses were surprising. "Always" and "sometimes" had the highest percentages which amount to $90 \%$ although the first four items are considered wrong behaviors according to teaching and learning theories that call for the students' involvement and relative independence while doing activities such as home assignments and projects. This can be justified in two ways: First, the respondents are not aware that these behaviors are wrong from an educational point of view. They tend to do them pushed by sympathy with their kids especially when the assignments are challenging as the case in international schools. They don't know that when they give instant help to their kids, they make them lose golden chances for learning through trying word attack skills and searching the internet or joining their classmates into team work and cooperative learning. (Meyer, Haywood, Sachdev, \& Faraday, 2008; and DeLong, 2009) emphasized 'student-centered learning' and 'ownership' of learning which involve building a strong relationship between teachers and students that enables students to become independent. Two types of factors were mentioned in this context: Internal factors that include cognitive skills such as problem solving, metacognitive skills and affective skills related to feelings and emotions and external factors related to teaching strategies that encourage independent learning. The other reason is that the respondents thought all the items were written positively and didn't bother to read carefully and understand the 
meaning although the items are translated into their L1. What makes the second justification stronger is their response to item five which calls for independent learning.

It is apparent in chart 3 that respondents value the logistic help and consider it as important as the direct help in teaching and learning. Providing a motivating environment free from anxiety and disturbances is very important. A quality home environment and parental support can contribute towards a student's motivation for academic achievement and learning, which can in turn increase interest in and satisfaction at school (Mansour\& Martin, 2009) cited in Emerson et al. (2014). Co-curricular activities including journeys, exhibitions, excursions, seminars and recreation centers are as educational as the classroom. Ingale, (2014) pointed out that co-curricular activities are needed in addition to the curriculum to develop a child intellectually, physically, sensibly socially and morally. The hidden curriculum where kids learn patterns of behavior indirectly from their parents, elder brothers and the people around them are sometimes better chances for learning than preaching and direct instruction. Alsubaie (2015) highlighted the importance of the hidden curriculum in shaping the character of the child and pointed out that this type of curriculum should be taken into consideration as it may have negative influences. When the parents follow rules of etiquette while dealing with each other, this becomes part of the kid's schema and he/she will use it when put in the same situation. When the family divides the day in a way that there are portions of time for sleep, food, fun, study and exercise, the kid knows that time is valuable and he shouldn't spend more time on fun and forget about study, sleep or exercise.

In few items where the father's involvement is demanded "sometimes" has a higher percentage than "always" as shown in the chart above. This is very natural in an environment like KSA as the father is most of the time busy away from home and women can't drive to take kids for outdoor activities.

\section{Conclusion and Recommendations}

This study investigated Saudi parents' perceptions of the kind of help they offer to their kids with regard to three areas: their relation with teachers and how this relation should reflect positively on kids' success and development. The concept that parents only visit schools when there is a problem or when they are called by principals should be substituted with a healthy relation based on mutual understanding, respect and cooperation between parents and teachers. It is now very common as shown in chart1 in the results that parents come to school to express their gratitude and appreciation other than complain and settle disputes. Parents may visit school to attend training, seminars and workshops about how to work in a parallel line with teachers and to consolidate and further practice what the teacher had already started in the classroom. The other area discussed in the study is the Saudi parents' perceptions to the academic help they offer to their kids. This help is considered necessary because teachers alone can't do everything especially in early years of the kid's academic life. Kids need the aforementioned consolidation and practice to master the skills which is impossible in the limited time of the classroom. Not all parents are able to provide the needed extension of school at home because they may not have enough qualification to do so. Furthermore, some traditionally taught parents may follow wrong approaches in helping their kids such as grammar translation or spoon-feeding. This creates a real need for more cooperation and coordination between parents and teachers. The third area is related to the logistic support that parents give to their kids in terms of providing a healthy motivating environment at home, offering their kids the chance for co-curricular activities, field trips, competitions and book and art exhibitions. These three areas are integrated and all contribute to a successful future for kids which is the ultimate goal for any teaching/learning process. More research in this critical area is recommended to enrich the fields of cooperation between parents and teachers.

\section{Acknowledgments}

I would like to thank the educational supervisor Mrs Fawzeyeh Al-Haidary from the Saudi Directorate of Education for her help in designing the questionnaire and sending it through google. I would also like to thank all the parents who responded to my questionnaire as well as my family for sacrificing their entertainment while I was busy doing the research.

\section{References}

Academic Development Institute. (1984). A Guide for Parents: Helping your child succeed in school. Research, publishing, training 121 N. Kickapoo St., Lincoln, IL 62656 217.732.6462, 1.800 759.1495. Al-Mahrooqi, R., Denman, C., \& Al-Maamari, F. (2016). “Omani Parents' Involvement in Their Children's English Education". SAGE Open, 1-12.

Alsubaie, M. A. (2015). Hidden Curriculum as One of Current Issues of Curriculum. Journal of Education and Practice, 6(33), 125-128. 
Al Sumaiti, R. (2012). Parental Involvement in Education of their Children in Dubai, Dubai School of Government., Policy Brief, No. 30, 1-8.

Bempechat, J. (1992). The Role of Parent Involvement in Children's Academic Achievement. The School Community Journal, 2(2), 31-41.

Center for Child Well-Being. (2012). Importance of Parental Involvement in their Child (ren)'s Learning, Research Bytes.

De Long, S. (2009). Teaching Methods to Encourage Independent Learning and Thinking, This paper was completed and submitted in partial fulfillment of the Master Teacher Program, a 2-year faculty professional development program conducted by the Center for Teaching Excellence, United States Military Academy, West Point, NY, 2009.

Emerson, L., Fear. J., Fox, S., \& Sanders, E. (2012). Parental engagement in learning and schooling: Lessons from research. A report by the Australian Research Alliance for Children and Youth (ARACY) for the Family-School and Community Partnerships Bureau: Canberra.

Graham-Clay, S. (2005). Communicating with Parents: Strategies for Teachers. The School Community Journal, 119-129.

Ingale, A. R. (2014). Role of Co-Curricular Activities in Students' Life. Scholarly Research Journal for Humanity Science \& English Language, 1(4), 592-594.

Lebopa, M. R. (2010). The Significance of parental Involvement in Early Childhood Learner Development in Mafikeng Rural Schools, Master of Education.

Linse, C., Vlack, S. V., \& Bladas, O. (2014). Parents and young learners in English language teaching: global practices and issues in school-home contacts. ELT Research Papers 14.04. British Council, Queen's University, Belfast.

Mafa, O., \& Makuba, E. (2013). The Involvement of Parents in the Education of their Children in Zimbabwe's Rural Primary Schools: The Case of Matabeleland North Province. Journal of Research \& Method in Education, 1(2), 37-43. https://doi.org/10.9790/7388-0133743

Meyer, B., Haywood, N. Sachdev, D., \& Faraday, S. (2008). What is independent learning and what are the benefits for students? London: Department for Children, Schools and Families Research Report 051, 2008.

Moosa, S., Karabenick, S.A., \& Adams, L. (2001). Teacher Perceptions of Arab Parent Involvement in Elementary Schools. School Community Journal, 11, 7-26.

Paulu, N. (1998). Helping Your Students with Homework, A Guide for Teachers, Edited by Linda B. Darby, Illustrated by Margaret Scott, Office of Educational Research and Improvement U.S. Department of Education.

Peters, M., Seeds, K., Goldstein, A., \& Coleman, N. (2008). Parental Involvement in Children's Education 2007. Research Report. DCSF RR034.

\section{Appendix A}

\section{The questionnaire used in the study}

Dear Parents,

It gives me great pleasure to share with you this questionnaire about the nature of help parents can give to their primary school kids. Your cooperation and contribution to my research is highly appreciated and definitely will result in great benefit to our kids.

$$
\begin{aligned}
& \text { أعز ائي الاباء و الأمهات } \\
& \text { يسعدني جدا أن أشارككم في هذه الأستبانة حول طبيعة المساعدة التي يقدمها الو الدان لأطفالهم في المرحلة الأساسية. أثن عاليا مساعدتكم }
\end{aligned}
$$

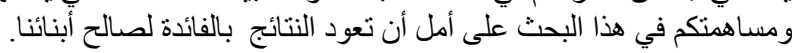

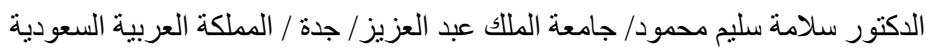


Appendix 1. A questionnaire about the nature of help parents give to their primary school kids

\begin{tabular}{llllll}
\hline No. & Item & Always & Sometimes & rarely & Never \\
\hline
\end{tabular}

Relation with teachers

ملامح العلاقة بين الو الدين و المدرسين فيما يتطلق بمصلحة الأطفال

1 I keep in touch with teachers

أبقى على إنصال مع المدرسين

2 Teachers phone me when my child misses an assignment or does poorly in exams.

يتصل بي المدرسون عندما يقصر طفلي في حل أحد الواجبات

3 I let the teacher know I am watching my child's study habits and attitude towards school

أعلم المدرس أنني مطلع على عادات طفلي الدراسية و إتجاهاته نحو

المدرسة

$4 \quad$ I ask the teacher how I can support my child in areas he/she may need to improve

أسأل الدرس كيف يمكن أن أساعد طفلي عندما يحتاج المساعدة

5 I share any information that might help the teacher understand my child

$$
\text { أطلع المدرس على أي معلومات يمكن أن تساعده في فهم طبيعة ولدي }
$$

6 I get a teacher tutor my kid if he has gaps in certain areas.

أستعين بدرس خصوصي إذا كان لدى طفلي فجوات في بعض إضع المو اضيع.

7 I thank the teacher when I appreciate something he has done for my child

$$
\text { لا أفوت الفرصة لثكر المدرس عندما أرى أنه يستحق الثكر }
$$

8 The first man to consult is the teacher if my child is struggling with homework.

إذا إستصعب طفلي بعض الواجبات ألجأ للددرس كثريك للتوصل الى حل يساعد طفلي

9 I make sure that my teaching strategies go with the teachers' strategies.

عندما أساعد طفلي أتأكد أن أساليبي تنسجم مع أساليب المدرس لكي نكون معا على إنسجام

The nature of academic help parents can give to their kids at home

طبيعة مساعدة الو الدين الأكاديمبة لطفلهما في البيت

10 Whenever he has a difficult word in English I give him the Arabic meaning.

عندما يو اجه مفردة صعبة أعطيه المعنى باللغة العربية

11 I make him read texts and give him the Arabic translation.

أجعله يقر ا نصا معينا وأزودة بالترجمة العربية لذلك النص

12 When he can't answer comprehension questions I answer for him

عندما لا يسنطيع إجابة بعض أسئلة الأستيعاب القرائي أقدم له الأجابة 
13 I give him the instructions in Arabic.

أعطيه تعليمات التمارين باللغة العربية

14 I encourage my child to work independently. If my child asks for help, I listen and provide guidance, not answers

أشجع طفلي للعمل بإستقلالية. إذا طلب مساعدة أستمع اليه وأرشده ولا

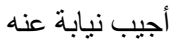

15 I watch my children for signs of frustration or failure. I let them take a break or talk through difficulties

أراقب أطفالي في لحظات الأحباط والفشل. أعطيهم فرصة للراحة ومناقثة العو ائق

16 I have my children do harder work first, when they are most alert. Easier work will seem to go faster after that

أجعل أطفالي يبداوون بالمهام الصعبة أولا عندما يكونون في أوج

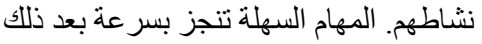

17 I check my child's diary to know his assignments every day.

$$
\text { أطلع على مفكرة طفلي للإطلاع على واجباته بشكل يومي }
$$

\section{Logistic indirect help for kids}

مساعدات لوجستيه غير مبانرة لأطفالي

18 I join SNS groups with parents to follow up with assignments and exams.

أنضم الى مجموعات وسائل الأتصال الأجنماعي لكتابعة واجبات و إختبار ات أطفالي

19 I attend PTA meatings to give suggestions and discuss ideas related to improving teaching strategies.

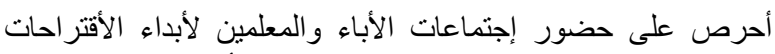
المتعلقة بتطوير الأستر اتيجيات التعليمية الأبرات

20 I take time to understand my children's world - their friends, activities, etc.

أحرص على فهم عالم طفلي, أصدقاءه والأنشطة التي يقوم بها

21 I go with my children to places where learning is a family activity

أصطحب أطفالي لأماكن يوجد فيها فرص تعليمية للعائلة ككل

22 I make daily study time a "family value," something each child does with or without homework assignments from school

أخصص وقت للار اسة أثناء اليوم كقيمة عائلية سواء كان هناك و اجبات أو لا

23 I make sure the home environment is welcoming and motivating to study.

أحرص على أن تكون بيئة البيت جاذبة ومشجعة للار اسة

24 I establish a family routine with regular mealtimes, bedtimes, homework time, and outdoor play/exercise time

أوسس لبرنامج للأسرة يشتمل على وقت للأكل ووقت للنوم ووقت لحل 
الواجبات ووقت للترفيه ووقت للرياضة

25 I show and model courtesy when talking with my children by using please, thank you

أكون مثالا جيدا لحسن التصرف لأطفالي و أنحدث معهم بلغة تعكس ذلك الكار بإستخدام عبار ات من فضلك بلفة وشكر ا...

26 I spend a few minutes daily with each child, talking and listening with patience and love

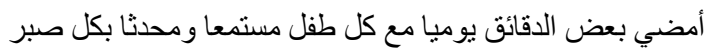

27 I praise my child for real effort and good attitudes about school work

أمدح و أعزز طفلي على جهده و إتجاهاته الجيدة نحو المدرسة

28 I pick a time when my children will study each evening; I don't let them wait until just before bedtime

أختار وقتا للار اسة كل مساء. لا أدعهم يؤجلوا الدراسة للحظات ما قبل النوم تابل

29 I try to do some of my own "homework" while my child studies, such as bill paying, reading, writing,

أحاول عمل واجباتي مثل دفع الفو اتثر والقراءة والكتابة أثناء إنشغال

أطفالي بو اجباتهم

Adapted from: Academic Development Institute, (1984) A Guide for Parents: Helping your child succeed in school. Research, publishing, training 121 N. Kickapoo St., Lincoln, IL 62656 217.732.6462, 1.800.759.1495.

\section{Copyrights}

Copyright for this article is retained by the author(s), with first publication rights granted to the journal.

This is an open-access article distributed under the terms and conditions of the Creative Commons Attribution license (http://creativecommons.org/licenses/by/4.0/). 